to the Geographical Journal, Vols. 1-5, Numbers 1-41 : 1918-1932" (London : Royal Geographical Society. 16s.: to fellows, 12s. 6d.). The terminal date is chosen as coinciding with the termination of the "Fourth General Index" to the Geographical Journal. The volume also serves as an index to much of the contents of the annual volumes of the Bibliographie Géographique Internationale, for which decennial tables have not recently been issued, the volume numbers in the Index giving the date of publication to within five years.

The Index which is thus made available is under one alphabet, giving authors and regional names in heavy type. Comprehensive headings are subdivided by italic headings, thus greatly facilitating reference. Thus under British Empire the subdivisions are agriculture and forestry, communications, defence, economics, education, history, mineral resources, politics, population, power, survey, text-books and travel. The lack of a rigid plan of subdivision and the adoption in each large grouping of one suitable for the character of the entries, are useful features. Considerations of space have limited each item to one subject entry. Titles in the less familiar languages are given in the language used in the summaries appended to the articles. Maps and photographs in the Society's collection are omitted, but all atlases are included.

\section{Composition of Scientific Papers}

EACH of our two leading medical contemporariesthe British Medical Journal and the Lancet-includes in the issues of January 2 some helpful suggestions to writers of scientific papers upon styles of composition and typographical conventions. The British Medical Journal is given a much more attractive appearance than it has had hitherto by the use of a cover of grey paper with a scarlet design upon it, and the type of the journal has been entirely changed, being now that created a few years ago for the printing of The Times. This type is more legible than that formerly used and is particularly suitable for com. fortable reading. The British Medical Journal announces in the same issue that, in future, the Harvard system of references to scientific literature will be used, instead of numbered references, such as are used in NaturE. Examples are given of these two systems of references to papers. The Lancet publishes a special supplement containing advice to authors on the preparation of scientific papers, words and phrases to avoid, summaries, abbreviations, references, and related matters. If these instructions were followed generally, the work of editors would be greatly relieved.

\section{Air Raid Precautions}

Air Raid Precautions Handbook No. 4 is entitled "Decontamination of Materials" (London : H.M. Stationery Office, 1936. 6d.), and deals with contamination caused by chemical substances capable of giving off poisonous gases. These gases are classified as non-persistent and persistent, the book dealing chiefly with the latter, which include the tear gases (ethyl iodoacetate or K.S.K., and bromobenzyl cyanide or B.B.C.) and the blister gases (mustard gas and lewisite). Decontamination of tear gases can be effected by using water, earth or a mixture of glycerin and caustic soda according to circumstances. Decontamination due to blister gases includes ventilation, hosing with water, removal by solvents, several methods of applying bleaching powder, immersion in boiling water, covering with earth, and destruction of the contaminated article by burning. In all cases, identification of the poison gas should precede attempts towards decontamination, and the latter should therefore be carried out only by persons specially trained and thoroughly protected. Ap. pendixes in the manual deal with the equipment of a decontamination squad and methods of dealing with road surfaces, the structures of buildings, household articles and vehicles.

\section{Colorado Potato Beetle}

$I_{N}$ consequence of the spread of the Colorado potato beetle from France and Belgium into Germany and Luxemburg, the Ministry of Agriculture and Fisheries has made an order "The Importation of Plants (Amendment No. 2) Order of 1936" regarding plant imports into Great Britain. The Order imposes restrictions on the importation from Germany and Luxemburg of certain kinds of horticultural produce as from January 11. The restrictions are similar to those already in force with respect to like produce from France and Belgium. The provisions of the order require a certificate in one of two forms to accompany living plants, potatoes, raw vegetables and cider apples imported from the countries mentioned. Copies of the Order (S. R. and O. 1936, No. 1288), price $1 d$. each net, may be obtained from H.M. Stationery Office, Adastral House, Kingsway, London, W.C.2.

\section{Campaign against Noise}

THE Leningrad Institute for the Protection of Labour is doing much useful work in combating the noise of machinery in Soviet factories. Some two hundred silencers of special design have been fitted to the automatically driven lathes of Leningrad factories manufacturing electrical apparatus. It is claimed that these silencers reduce the noise of the machines to the loudness of the normal human voice. The Institute is also carrying out experiments to reduce the noise of machinery at other types of works and factories and on the motor-ships of the Black Sea. During the past year the Institute has received more than twenty different designs for silencers from Soviet engineers and factory workers.

\section{Earthquake in Kent on December 29}

Ar about 1.30 p.m. on December 29, a very slight earthquake, accompanied by a rumbling sound, was felt in the east of Kent. The villages in which it was observed (Adisham, Nonington, Snowdown, etc.) are close to the centre of the area disturbed by the much stronger Canterbury earthquake of November 27, 
1776, that was felt with some intensity (about 6, Rossi-Forel scale) at Canterbury, Sandwich, Deal, Dover, Folkestone and Ashford, and, though very slightly, at Calais, thirty-four miles from the centre.

\section{Sands, Clays and Minerals}

THE most recent issue of this journal (3, No. 1, November 1936. A. L. Curtis, Westmoor Laboratory, P.O. Box 61, Chatteris, Cambridgeshire, price $3 s .6 d$.) has been considerably enlarged and contains articles covering a wide range of subjects. Topies of economic importance dealt with in this number include nickel, silica sand as a basis for phosphate deficiency tests on lettuce, minerals of Brazil, titanium oxide in industry, boron, soils, industrial water supply, barytes in Greece, mining resources in Tanganyika, etc. The articles are written by authors actually engaged in research on the subject, thus making them authoritative. A contribution by A. L. Curtis on the history and activities of the Fuel Research Station at Greenwich makes interesting reading. The journal is attractively produced, and is an excellent source of information, especially for mineralogists, chemical engineers and other men of science and technology concerned particularly with the mineral resources of the British Empire.

\section{Physical Society's Exhibition Catalogue}

THe Catalogue of this Exhibition, which was open on January 5-7, now covers nearly 200 pages and is well provided with indexes of exhibitors and of apparatus, plans, stall numbers on the outer top corner of each page, marks for new apparatus and for demonstrations, all of which help a visitor to find readily what he wants particularly to see. Illustrations are plentiful, but many are limited to views of the outsides of the boxes containing the instruments, while the interest of the visitor is more often centred in the principle of the instrument itself. The division of the catalogue into two sections devoted respectively to trade exhibits and research and educational exhibits is maintained, and the award of prizes to apprentices for exhibits of work done is continued. A new announcement is made of the intention of the Council to apply part of the legacy bequeathed to the Society by the late Herbert Spencer, for grants to fellows for the purchase of special research apparatus. The order of the stands in the catalogue and their stand numbers are arranged geographically to facilitate reference, and the asterisk which now marks a new exhibit in the body of the eatalogue might with advantage in future years appear also in the apparatus index.

\section{Announcements}

Str WILITAM BragG will open the new extension to the Research Laboratories of the British Association of Research for the Cocoa, Chocolate, Sugar Confectionery and Jam Trades and the British Food Manufacturers' Research Association at 2 and 4, Dalmeny Avenue, Holloway, London, N.7, on January 19. There will be a reception from 3 until 6 p.m.
THE King has been pleased, on the recommendation of the Secretary of State for Scotland, to approve the appointment of Prof. Lancelot Hogben, professor of social biology in the University of London, to be regius professor of natural history in the University of Aberdeen, in succession to Prof. James Ritchie. Prof. Hogben was formerly assistant professor of zoology in McGill University, Montreal, and professor of zoology in the University of Cape Town.

Mr. N. B. KInNEAR and Dr. H. A. Baylis have been appointed to deputy keeperships in the Department of Zoology of the British Museum (Natural History). Mr. Kinnear was born in 1882 and is a great-grandson of Sir William Jardine, the early nineteenth century naturalist. $\mathrm{He}_{\mathrm{e}}$ is well known as an ornithologist, and prior to his appointment to the Museum sixteen years ago was in charge of the Bombay Natural History Society's Museum. He is the editor of the Bulletin of the British Ornithologists' Club. Dr. Baylis was born in 1889 and was educated at Epsom College and Jesus College, Oxford. $\mathrm{He}$ entered the Museum in 1912, and has specialized throughout his eareer in parasitic worms. $\mathrm{He}_{\theta}$ is the author of many scientific papers on this subject, and has built up a very large collection of these organisms, of which, before his time, the Museum possessed only a few specimens.

Prof. P. M. S. BLAcketr will deliver the Cantor Lectures before the Royal Society of Arts on January 18, 25 and February 1. The subject of the lectures will be "Cosmic Rays".

The Sir Halley Stewart Trust has placed at the disposal of the Medical Research Council a sum of $£ 500$ a year for three years for a senior fellowship tenable in the Neurological Research Unit at the National Hospital for Nervous Diseases, Queen Square, London. This arrangement has been gratefully accepted by the Council with the concurrence of the Medical Committee of the Hospital, and the position has been awarded to Dr. Joseph Doupe.

THE seventy-first volume of the Journal of Anatomy is termed the "Elliot Smith Volume" and is dedicated to Sir Grafton Elliot Smith (see p. 57). Appropriately enough, Part 1, which was issued last October, contains his portrait as a frontispiece and commences with a biographical sketch of his early career by Prof. J. T. Wilson, who, in his early years in the Challis chair of anatomy in the University of Sydney, included Elliot Smith among his students.

MR. B. D. W. Morrey, of "Holy Trinity Vicarage, Madeira Road, Bournemouth, Hants, asks anyone who has been studying, or has at any time studied, communication among ants, to get in touch with him.

Wrul Mr. Paul Molde, of Copenhagen, who sent a communication to the Editor entitled "On the Atomic Structure of Living Matter : A Biole Hypothesis", kindly communicate his address. 